\title{
A Diffuse Alveolar Hemorrhage in a Human T-lymphotropic Virus Type I Carrier with Acute Cerebellar Ataxia and Interstitial Pneumonitis: An Autopsy Case Report
}

\author{
Makoto Tajima, Hitoshi Arioka, Junichi Nakano, Takashi MiYasaka, Machiko Murata, Naomi Yamashita, \\ Kenji Mano, Tomohide Sato, Hideyuki HaEbara* and Ken Ohta
}

\begin{abstract}
A 76-year-old HTLV-I-positive male with acute cerebellar ataxia was suffering from dyspnea on exertion. Chest CT suggested interstitial pneumonitis. Methylprednisolone pulse therapy improved his symptoms and chest CT findings. Twelve months after discharge, when the prednisolone dose was tapered to $5 \mathrm{mg}$ every other day, his lung lesion recurred. The lesion responded initially to steroid therapy. However, hypoxemia intractable to steroid pulse therapy developed and the patient died of respiratory failure. The autopsy revealed diffuse alveolar hemorrhage with no finding of vasculitis. This is the first case report of diffuse alveolar hemorrhage in an HTLV-I carrier.

(Internal Medicine 39: 166-169, 2000)
\end{abstract}

Key words: HTLV-I, methylprednisolone pulse therapy, antiHTLV-I antibody

\section{Introduction}

Human T-lymphotropic virus type I (HTLV-I) is a retrovirus which is endemic to the south of Japan and Caribbean countries. This virus was first known to cause adult T-cell leukemia/lymphoma (ATL) (1). Gessain et al (2) and Osame et al (3) independently reported another disorder caused by the virus, which is slowly progressive myelopathy (HTLV-I-associated myelopathy/HTLV-I-associated tropical spastic paraparesis, HAM/TSP). To date, it is known that $30-50 \%$ of HTLV-I positive cases show abnormality in the lung, which was termed HTLV-I-associated bronchopneumonopathy (HAB) by Maruyama et al (4). We report a case with positive HTLV-I antibody and neuromuscular abnormality, in whom an interstitial lung lesion developed and lethal diffuse alveolar hemorrhage occurred.

\section{Case Report}

A 76-year-old man who was a native of Nagasaki prefecture, the southwest of Japan, was admitted to Teikyo University Hospital in July 1996 for gait disturbance and dysarthria. The patient was suspected as HAM/TSP because of high antiHTLV-I antibody titer in serum $(\times 4,096)$. The diagnosis was not, however, confirmed since the anti-HTLV-I antibody in the spinal fluid was $\times 8$ and brain MRI finding was normal. Serum and spinal fluid antibodies against adenovirus, mumps virus, cytomegalovirus, herpes simplex virus, varicella zoster virus, rubivirus and Epstein-Barr virus, and serum mycoplasma antibody were all within normal limits. During this admission, he suffered from dyspnea on exertion. Partial pressure of arterial oxygen $\left(\mathrm{PaO}_{2}\right)$ under room air was 60.7 Torr. Chest CT revealed bilateral ground glass appearance and fine reticular shadow suggesting interstitial pneumonitis (Fig. 1). However, the results of bronchoalveolar lavage and transbronchial biopsy which were performed after steroid therapy were unremarkable. Repeated methylprednisolone pulse therapy improved dyspnea, $\mathrm{PaO}_{2}$, and CT findings (Fig. 1) as well as his neurological signs and symptoms. Serum and spinal fluid antiHTLV-I antibody titer was decreased to $\times 512$ and to $\times 2$, respectively. He was transferred to another hospital for rehabilitation in January 1997 on $30 \mathrm{mg}$ oral daily prednisolone. Serum anti-HTLV-I antibody titer was $\times 256$ on admission to the hospital, which was increased to $\times 512$ in May 1997, when he was discharged from the hospital on $15 \mathrm{mg} /$ day of oral prednisolone.

On January 1 1998, after oral prednisolone was tapered to 5 mg every other day, the patient was emergently admitted because of severe dyspnea and weakness in bilateral lower extremities. On physical examination, fine crackles were noted on bilateral lung fields particularly on his back. Neurological examination revealed weakness and decreased tendon reflexes on lower extremities. Laboratory data showed elevation of serum anti-HTLV-I antibody titer to $\times 1,024$, increased serum LDH

From the Department of Medicine and *the Department of Pathology, Teikyo University School of Medicine, Tokyo

Received for publication July 5, 1999; Accepted for publication October 25, 1999

Reprint requests should be addressed to Dr. Ken Ohta, the Department of Medicine, Teikyo University School of Medicine, 2-11-1 Kaga, Itabashi-ku, Tokyo 173-8605 


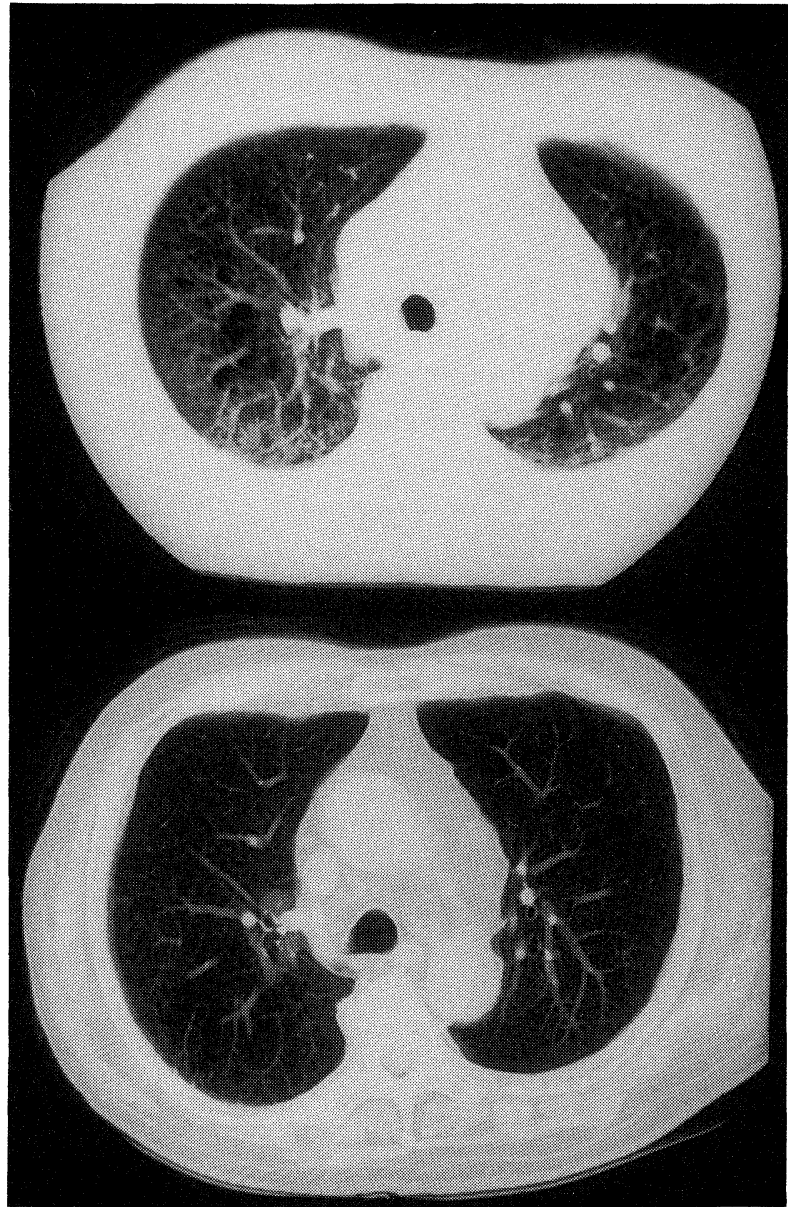

Figure 1. Chest CT in the first admission. Diffuse interstitial change (top) improved after methylprednisolone pulse therapy (bottom). level, and hypoxemia (Table 1). Chest X-ray and CT findings suggested a recurrence of interstitial lesion. Steroid pulse therapy and $60 \mathrm{mg}$ daily of oral prednisolone improved his $\mathrm{PaO}_{2}$ and chest X-ray to some extent. The patient had, however, rapidly progressing dyspnea on the 40th hospital day. Chest X-ray showed diffuse infiltrative shadow (Fig. 2). There were no abnormal laboratory data including platelet count, prothrombin time or activated partial thromboplastin time. Serum anti-HTLV-I antibody titer was still $\times 1,024$ then despite highdose glucocorticoid therapy. Methylprednisolone pulse therapy

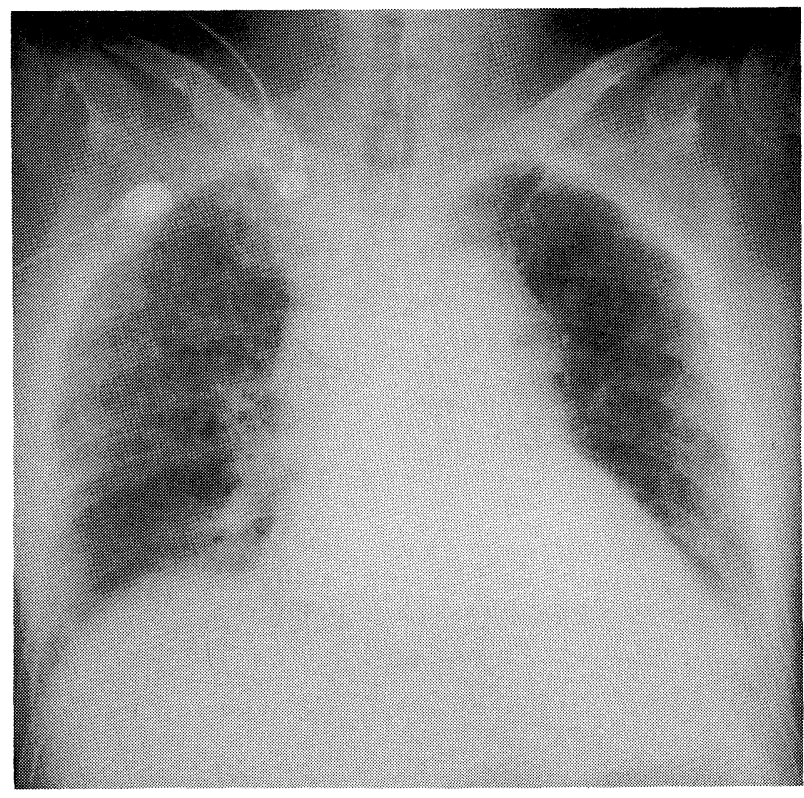

Figure 2. Chest $X$-ray in the second admission when the patient was suffering from rapidly progressing dyspnea. There was a diffuse infiltrative shadow throughout the lungs.

Table 1. Laboratory Data on the Second Admission

\begin{tabular}{|c|c|c|c|c|c|}
\hline Urinalysis & \multicolumn{3}{|c|}{ Biochemistry } & $\mathrm{Na}$ & $139 \mathrm{mEq} / \mathrm{l}$ \\
\hline Protein & $(-)$ & $\mathrm{TP}$ & $6.8 \mathrm{~g} / \mathrm{dl}$ & $\mathrm{K}$ & $4.0 \mathrm{mEq} / \mathrm{l}$ \\
\hline Glucose & $(-)$ & Alb & $59.2 \%$ & $\mathrm{Cl}$ & $102 \mathrm{mEq} / \mathrm{l}$ \\
\hline Occult blood & $(-)$ & $\alpha_{1}-\mathrm{gl}$ & $3.2 \%$ & Serology & \\
\hline Hematology & & $\alpha_{2}-\mathrm{gl}$ & $9.9 \%$ & CRP & $0.7 \mathrm{mg} / \mathrm{dl}$ \\
\hline $\mathrm{RBC}$ & $450 \times 10^{4} / \mu \mathrm{l}$ & $\beta$-gl & $9.8 \%$ & IgG & $1,220 \mathrm{mg} / \mathrm{dl}$ \\
\hline $\mathrm{Hb}$ & $12.8 \mathrm{~g} / \mathrm{dl}$ & $\gamma-\mathrm{gl}$ & $17.9 \%$ & IgM & $64 \mathrm{mg} / \mathrm{dl}$ \\
\hline $\mathrm{Ht}$ & $43.3 \%$ & T-Bil & $0.7 \mathrm{mg} / \mathrm{dl}$ & $\operatorname{IgA}$ & $133 \mathrm{mg} / \mathrm{dl}$ \\
\hline WBC & $6,700 / \mu 1$ & AST & $26 \mathrm{IU} / \mathrm{l}$ & HTLV-I Ab & $\times 1,024$ \\
\hline Neut & $83 \%$ & ALT & $23 \mathrm{IU} / l$ & BGA & \\
\hline Eo & $0 \%$ & $\mathrm{LDH}$ & $467 \mathrm{IU} / l$ & $\mathrm{pH}$ & 7.45 \\
\hline Baso & $0 \%$ & ALP & $215 \mathrm{IU} / l$ & $\mathrm{PaCO}_{2}$ & 37 Torr \\
\hline Lym & $12 \%$ & $\gamma$-GTP & $21 \mathrm{IU} / l$ & $\mathrm{PaO}_{2}$ & 67 Torr \\
\hline Mo & $5 \%$ & BUN & $15.7 \mathrm{mg} / \mathrm{dl}$ & $\mathrm{HCO}_{3}^{-}$ & $25.7 \mathrm{mEq} / \mathrm{l}$ \\
\hline Plt & $25.6 \times 10^{4} / \mu 1$ & $\mathrm{Cr}$ & $0.8 \mathrm{mg} / \mathrm{dl}$ & $\mathrm{BE}$ & $1.9 \mathrm{mEq} / \mathrm{l}$ \\
\hline ESR & $4 \mathrm{~mm} / \mathrm{h}$ & UA & $5.5 \mathrm{mg} / \mathrm{dl}$ & $\mathrm{SaO}_{2}$ & $92 \%$ \\
\hline & & BS & $113 \mathrm{mg} / \mathrm{dl}$ & & \\
\hline
\end{tabular}



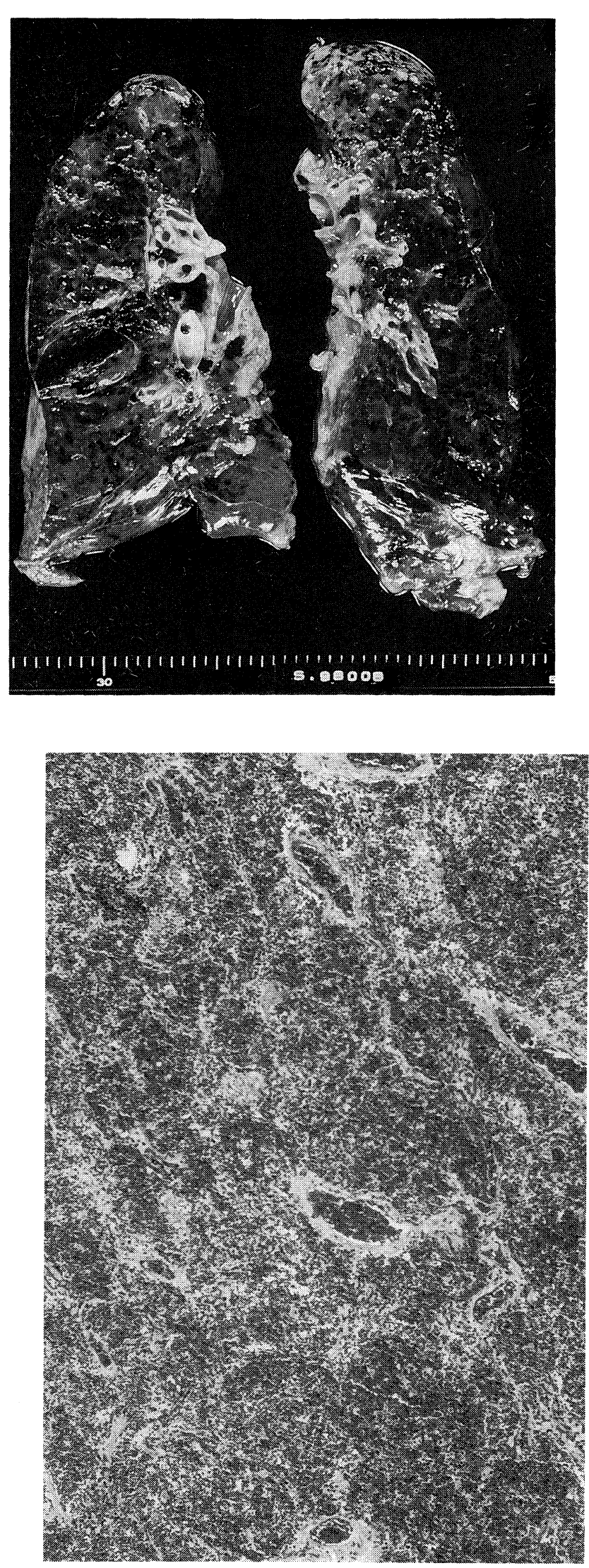

was performed again since exacerbation of interstitial pneumonitis was suspected. Despite aggressive treatment including mechanical ventilation, respiratory failure progressed and the patient died on the 47 th hospital day.

Autopsy revealed hemorrhage throughout bilateral lungs (Fig. 3). Lung weights were $595 \mathrm{~g}$ for the left lung and $760 \mathrm{~g}$ for the right. Bleeding was found only in the lungs. Microscopically, marked alveolar hemorrhage without vasculitis was found (Fig. 4). There was no finding indicating systemic vasculitis and HTLV-I-associated myelopathy. There was only findings suggesting acute hemostasis in his kidneys. In the cerebellum, there were vacuolar formation in the Purkinje cell layer and sporadic disappearance of Purkinje cells.

\section{Discussion}

HTLV-I causes a variety of systemic disorders such as myelopathy (HAM/TSP), uveitis, sicca syndrome, and polymyositis, as well as ATL. We treated an HTLV-I-positive case who

Figure 3. Macroscopic findings of the lung at the autopsy, showing marked hemorrhage in both lungs.

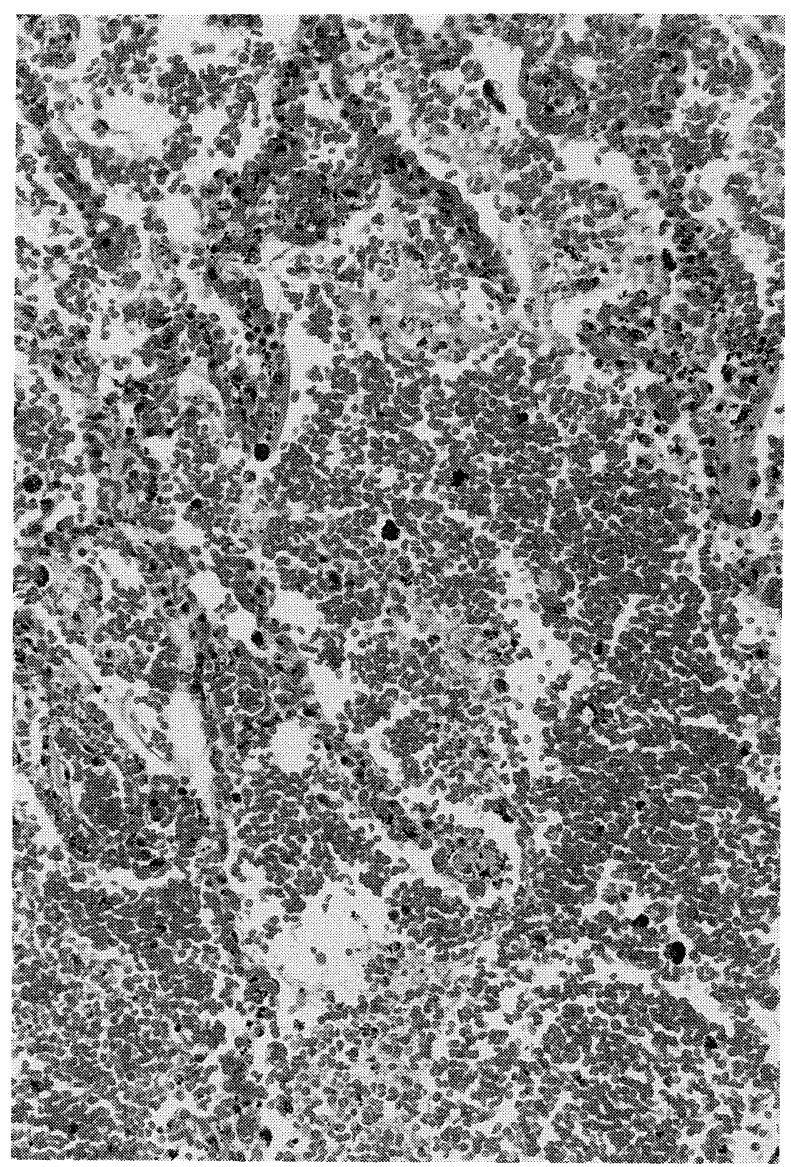

Figure 4. Microscopic findings of the lung showed diffuse alveolar hemorrhage (HE stain; left, $\times 40$; right, $\times 100)$. There was no finding suggesting vasculitis. 
had acute cerebellar ataxia, interstitial lung lesion, and alveolar hemorrhage. We could not link acute cerebellar ataxia seen in this patient to HTLV-I infection since no such report was published and anti-HTLV-I antibody titer in his spinal fluid was relatively low. The autopsy findings failed to demonstrate HTLV-I-associated neuropathy. The origin of his neurological abnormality is still unknown. However, we speculate that HTLV-I may have played some role in his ataxia, since his neurological findings were improved with steroid therapy followed by a decrease of serum anti-HTLV-I antibody titer from $\times 4,096$ to $\times 512$.

The involvement of the respiratory tract by HTLV-I is termed as HTLV-I-associated bronchopneumonopathy (HAB) by Maruyama et al (4). A typical chest X-ray finding of HAB is diffuse reticulonodular shadow particularly in the lower lung fields (5). Pathologically, HAB is characterized by infiltration of T lymphocytes to bronchiolar submucosa, alveolar walls and perivascular area (5). There are several reports describing lymphocyte infiltrates in peribronchiolar and perivascular regions or alveolar walls in HAM/TSP (6-8) and in ATL (9). We could not detect, however, pathological abnormalities including alveolar hemorrhage in the transbronchial lung biopsy specimen in this patient in the first admission. There was a possibility that methylprednisolone pulse therapy modified the interstitial change. Drug-induced lung disease was unlikely because no medication was given to the patient when his interstitial lung lesion was found. Anti-virus antibody titers on the first admission were normal so far as we examined. The interstitial lung disease appeared when serum anti-HTLV-I antibody level was relatively high $(\times 4,096$ and $\times 1,024$ on the first and the second admission, respectively). The lesion responded to steroid therapy. We thus consider that his interstitial lung lesion was related to HTLV-I infection.

There are several diseases which cause alveolar hemorrhage. Among these diseases, Goodpasture's syndrome and Wegener's granulomatosis could be differentiated since there was neither vasculitis nor renal impairment clinically and pathologically, although we did not examine anti-neutrophil cytoplasmic antibodies or anti-basement membrane antibody. The absence of typical symptoms and negative serum anti-nuclear antibody and rheumatic factor (data not shown) indicated that systemic lupus erythematosus was less likely. We ruled out idiopathic pulmonary hemosiderosis because of his age and the absence of hemosiderin-containing macrophages in the lungs.

There are reports of gastrointestinal bleeding due to intestinal ulcer in ATL patients (10), and cerebral hemorrhage due to vasculitis in a HAM patient (11). In this case, there was neither systemic bleeding tendency nor vasculitis. It has been reported that the incidence of alveolar hemorrhage was approximately $30 \%$ in autopsy of ATL patients (12), although there is no report describing diffuse alveolar hemorrhage in non-ATL HTLVI carriers. There was no hemorrhage throughout his body at autopsy except the lungs. Despite methylprednisolone pulse therapy, serum anti-HTLV-I antibody level was still $\times 1,024$ on the 40th hospital day of the second admission, when alveolar hemorrhage had occurred. Taking these findings together, we speculated that some unknown local mechanism(s) related to HTLV-I infection may cause alveolar hemorrhage in this patient, although there is a possibility that this event might have occurred only by chance.

In conclusion, this case suggested to us that it is necessary to consider diffuse alveolar hemorrhage in the differential diagnosis in lung diseases of HTLV-I-positive patients.

\section{References}

1) Takatsuki K, Yamaguchi K, Kawano F, et al. Clinical diversity in adult Tcell leukemia-lymphoma. Cancer Res 45: 4644s-4645s, 1985.

2) Gessain A, Barin F, Vernant JC, et al. Antibodies to human T-lymphotropic virus type-I in patients with tropical spastic paraparesis. Lancet 2: 407410, 1985.

3) Osame M, Usuku K, Izumo S, et al. HTLV-I associated myelopathy, a new clinical entity. Lancet 1: 1031-1032, 1986 (letter).

4) Maruyama I, Chihara J, Sakashita I, et al. HTLV-I-associated bronchopneumonopathy -A new clinical entity? Am Rev Respir Dis 137: 46, 1988 (Abstract).

5) Maruyama I, Mori S, Kawabata M, Osame M. Bronchopneumonopathy in HTLV-1 associated myelopathy (HAM) and non-HAM HTLV-1 carriers. Nippon Kyobu Shikkan Gakkai Zasshi (Jpn J Thorac Dis) 30: 775779, 1992 (in Japanese, Abstract in English).

6) Sugimoto M, Nakashima $\mathrm{H}$, Watanabe $\mathrm{S}$, et al. T-lymphocyte alveolitis in HTLV-I-associated myelopathy. Lancet 2: 1220, 1987 (letter).

7) Smadja D, Cabre P, Bellance R, Vernant JC. Paraplegia associated with HTLV 1 in Martinique. Study of 271 cases including 70 with neuromuscular involvement. Bull Soc Pathol Exot 86: 433-438, 1993.

8) Sugisaki K, Tsuda T, Kumamoto T, Akizuki S. Clinicopathologic characteristics of the lungs of patients with human $\mathrm{T}$ cell lymphotropic virus type 1-associated myelopathy. Am J Trop Med Hyg 58: 721-725, 1998.

9) Rose RM, O'Hara CJ, Harbison MA, et al. Infiltration of the lower respiratory tract by helper/inducer T lymphocytes in HTLV-1-associated adult T-cell leukemia/lymphoma. Am J Med 90: 118-123, 1991.

10) Nakasone T, Masuda M, Arakaki H, Shimoji T, Araki K, Mimura G. Adult T-cell leukemia with massive melena due to marked gastrointestinal involvement. Rinsho Ketsueki (Jpn J Clin Hematol) 30: 1848-1852, 1989 (in Japanese, Abstract in English).

11) Smith D, Lucas S, Jacewicz M. Multiple cerebral hemorrhages in HTLVI-associated myelopathy. Neurology 43: 412-414, 1993.

12) Tashiro T. Pulmonary complications in patients with adult T-cell leukemia. Nippon Kyobu Shikkan Gakkai Zasshi (Jpn J Thorac Dis) 30: 756762, 1992 (in Japanese, Abstract in English). 